RECENSÃO

\title{
SEPP, LUDWIG. Staat als irdischer Gott. Genese und Relevanz einer Hegelschen Idee. Tubinga: Mohr Siebeck, 2015. ISBN 978-3-16-153848-3.
}

\section{Artur Flamínio Da Silva}

Licenciado em Direito pela Faculdade de Direito da Universidade de Lisboa. Mestre e doutorando em Direito Público pela Faculdade de Direito da Universidade Nova de Lisboa. arturmicaelsilva@gmail.com

As manifestaçôes mais recentes da globalização têm posto em evidência as fragilidades de uma concepçáo do Direito exclusivamente centrada no Estado. No século 21 torna-se indispensável discutir e estudar o papel do Estado em uma Sociedade Global eminentemente fragmentada. ${ }^{1}$ Este contexto é bem-identificado por Ludwig Sepp quando, na primeira página da obra recenseada, afirma que "a consideração de que o Estado tem uma validade absoluta, de dignidade quase divina, parece pertencer ao passado". ${ }^{2}$

Este postulado é relevante, desde logo, porque esta constatação nada nos diz sobre a função do Estado em um contexto atual de descentralização do Direito (ou pelo menos da autoridade última daquele) na esfera estadual. Por outro lado, em uma dimensão ainda mais relevante, a mera invocação (ou a verificação) de um Direito Cosmopolita ${ }^{3}$ não resolve a questão que envolve saber qual o fundamento (ou a autoridade) de uma determinada normatividade.

1 Sobre este fenômeno, ver: Fischer-Lescano, Andreas; Teubner, Gunther. Regime-Collisions: the Vain Search for Legal Unity in the Fragmentation of Global Law. In: Michigan Journal of International Law, vol. 25, n. 4, p. 999 et seq., 2004.

2 Cfr. Sepp, Ludwig. Staat als irdischer Gott. Genese und Relevanz einer Hegelschen Idee. Tubinga: Mohr Siebeck, 2015. p. 1.

3 Sobre esta questão, ver: Krisch, Nico. Beyond Constitutionalism. Oxford: Oxford University Press, 2010. p. 3. Em língua portuguesa é, por outro lado, importante mencionar o estudo de Medeiros, Rui. A Constituição Portuguesa num contexto global. Lisboa: Universidade Católica Editora, 2015. passim. 
O texto de Ludwig Sepp é, portanto, manifestamente interessante e oportuno, embora a discussão que subjaz ao estudo recenseado possa ser reconduzida a um macrotema clássico: Qual o fundamento do Direito? Esta dificuldade parece ter sido bem-ultrapassada com a devida delimitação temática na sua introdução. $\mathrm{Na}$ verdade, a exposição crítica centra-se no idealismo de Hegel, estudando as implicaçóes da suposta divinização do Estado do pensamento hegeliano. ${ }^{5}$ No fundo, o autor desenvolve argumentos em torno dos problemas que envolvem a "absolutização" do Estado e a concepção daquele como um "Deus terreno" (irdischer Gott) no período histórico hodierno onde os mercados e as religióes ameaçam substituir-se ao Estado (ou pelo menos ameaçar aquele) no papel de centralização, tal como é concebido em termos clássicos. ${ }^{6}$

Em um plano formal, cumpre realçar que a escrita é, por sua vez, simples como é desejável em um tema difícil -, mas com evidente rigor científico. O texto ascende, por um lado, a um total de 268 páginas, englobando a bibliografia e um índice onomástico. Por outro lado, o estudo divide-se, excetuando a introdução, em seis partes: (i) uma parte sobre a soberania e os direitos individuais; (ii) uma parte sobre o bem-estar enquanto tarefa estadual; (iii) uma parte sobre o cumprimento da justiça no Estado secular; (iv) uma parte sobre o Estado divino e a liberdade de religiáo; (v) o Estado secular e os direitos da pessoa depois do fim do Estado absoluto; (vi) uma conclusão com o título: "a autoridade do Estado entre a religiáo e o mercado".

${ }^{4}$ Esta problemática já foi, por exemplo, ensaiada em língua portuguesa por Coutinho, Luís Pereira. $A$ autoridade moral da Constituição - da fundamentação da validade do Direito Constitucional. Coimbra: Coimbra Editora, 2009. passim.

5 É sabido que Hegel afirma, por exemplo e em uma frase sugestiva, que "o Estado é uma manifestação de Deus" (no original: "Der Staat ist selbst die Offenbarung Gottes in der Gegenwart und in der Wirklichkeit") [cfr. Hegel, Georg Friedrich Wilhelm. Philosophie des Rechts. Die Vorlesung von 1819/20 in einer Nachschrift. Frankfurt am Main: Suhrkamp, 1983, p. 223] ou em uma outra dimensão, inclusivamente, que: "o Povo enquanto Estado (...) é a absoluta autoridade na Terra" (no original: "Das Volk als Staat ist (...) die absolute Macht auf Erden”) (cfr. Hegel, Georg Friedrich Wilhelm. Grundlinien der Philosophie des Rechts oder Naturrecht und Staatswissenschaft im Grundrisse. Mit Hegels eigenhändigen Notizen und den mündlichen Zusätzen. Republicação em 20 volumes das obras de Hegel publicadas entre 1832-1845. Frankfurt am Main: Suhrkamp, 1986. p. 498).

6 Sepp, Ludwig. Staat als irdischer Gott. Genese und Relevanz einer Hegelschen Idee. Tubinga: Mohr Siebeck, 2015. p. 13. 
Em um plano substancial deve ser realçado que o autor identifica, em geral, quatro aspectos determinantes na concepção hegeliana do Estado como "Deus terreno". Em primeiro lugar, a "força do Estado" assenta: (i) no Estado enquanto entidade protetora dos indivíduos contra a violaçáo dos seus direitos; (ii) no Estado enquanto "unidade substancial" (embora não exclusiva) assume-se como condição para a existência de uma autêntica liberdade individual. Neste contexto, a "força do Estado", enquanto garante os direitos fundamentais, manifesta-se na existência de um Estado que é "independente de qualquer autoridade religiosa ou de qualquer poder 'privado"'?

Em segundo lugar, o poder estadual concretiza-se na existência de um "Estado Social" que concorre entre os séculos 18 e 19 com o poder das comunidades religiosas e com as forças do mercado emergente da Revoluçáo Industrial. De qualquer modo, não se pode deixar de constatar que, para Hegel, "o Estado não pode admitir a auto-realização individual colocando em causa o bem comum ou os bens que justificam a prossecução de interesses individuais". Com efeito, o Estado é, portanto, o garante do "bem social supremo". ${ }^{8}$

Em terceiro lugar, Hegel parte de uma "ideia" de Estado. Esta concepção manifesta-se, em primeiro lugar, na existência de um determinado povo que existe em um "espaço, tempo, natureza e história” específicos e, em segundo lugar, na constatação de um processo de pertença coletivo dos indivíduos (Volksgeist).

Por último, Hegel reforça o poder estadual com a crítica que desenvolve em torno da existência de um paternalismo moral das ordens religiosas e da insuficiente separação entre o Estado e a Igreja. Neste sentido, estabelece que o Estado deve determinar um espaço de autonomia individual de: (i) liberdade de religióes (autonomia individual para optar pela abstenção de adotar uma fé religiosa); (ii)

Ludwig Sepp. Staat als irdischer Gott. Genese und Relevanz einer Hegelschen Idee. Tubinga: Mohr Siebeck, 2015. p. 46-47.

8 Sepp, Ludwig. Staat als irdischer Gott. Genese und Relevanz einer Hegelschen Idee. Tubinga: Mohr Siebeck, 2015. p. 90-91, p. 96.

9 Sepp, Ludwig. Staat als irdischer Gott. Genese und Relevanz einer Hegelschen Idee. Tubinga, Mohr Siebeck, 2015, p. 126-127. 
liberdade para as religióes (autonomia individual de escolha de religiano e, inclusivamente, de trocar de religiáo); (iii) liberdade de manifestação (exterior) religiosa (autonomia individual de exteriorização da fé religiosa). ${ }^{10}$

Neste contexto, e em um espaço conclusivo, Ludwig Sepp reflete sobre uma discussão muito interessante e que pode, em termos gerais, formular-se do seguinte modo: Qual deve ser o papel do Estado ante as pressóes que sofre da força erosiva das manifestaçóes normativas transnacionais ou da força econômica do "mercados"? Assim, a tese que o autor da obra recenseada pretende desenvolver consubstancia uma solução salomônica que permite, em um quadro de perda de estadualidade, um compromisso em que o Estado tem ainda uma função moderadora. ${ }^{11}$

Em suma, o texto recenseado é interessante e actual. Em particular, deve realçar-se que a monografia de Ludwig Sepp permite ao leitor momentos de reflexão que podem permitir estudos mais abrangentes, lançando as bases para a importante discussão da função do Estado em um contexto pós-nacional.

Recebido em: 21/9/2015

Aceito em: 27/1/2016

${ }^{10}$ Segundo a enumeração de Sepp, Ludwig. Staat als irdischer Gott. Genese und Relevanz einer Hegelschen Idee. Tubinga: Mohr Siebeck, 2015. p. 165 et seq. e, em particular, p. 167.

${ }^{11}$ Sepp, Ludwig. Staat als irdischer Gott. Genese und Relevanz einer Hegelschen Idee. Tubinga: Mohr Siebeck, 2015. p. 189 et seq. 